\title{
Foreword to the English Translation
}

The best of all places to hide, typically, is in plain sight. Heidegger once called this "the inconspicuousness of the obvious." I call attention to this provocative suggestion because for many decades I have been at a loss to explain why there has been no English translation of Karl Löwith's magisterial Nietzsche study, Nietzsches Philosophie der ewigen Wiederkehr des Gleichen, ${ }^{1}$ while during these same decades the ruminations of virtually every European Nietzschescribbler-from the insightful to the laughable-have been translated and discussed. In the meantime, Löwith's Nietzsche remained shrouded in silence. The reason now seems both obvious and inconspicuous to me. It is entirely political. Löwith was a Jew, in early self-imposed exile from Nazi Germany (thanks to the Rockefeller Foundation); he was strikingly clearheaded about National Socialism at the very beginning of its hegemony in Germany; and he was an apostate student of Martin Heidegger who saw in Heidegger's unpublished Nietzsche studies as well as in his other writings an intrinsic affinity to Nazism. ${ }^{2}$ It has taken Anglophone scholarship more than half a century to recapture Löwith's insight.

1. Wiederkunft in the 1935 edition, Wiederkehr in the 1956 and subsequent editions.

2. This may also help to explain why some of Löwith's other books were translated into English or first published in English and were well received-e.g., Meaning in History (Chicago: University of Chicago Press, 1949); Nature, History, and Existentialism (Evanston, Ill.: Northwestern University Press, 1966); From Hegel to Nietzsche (New York: Holt, Rinchart and Winston, 1964)-while his incisive 1953 Heidegger study (Heidegger: Denker in dürftiger Zeit [Frankfurt am Main: S. Fischer Verlag]) was not translated until 1995 ("Heidegger: Thinker in a Destitute Time," in the volume of selections 
As J. Harvey Lomax points out in his Introduction to this volume, it took considerable courage for Gerhard Bahlsen, owner of the press "Die Runde," to publish Löwith's Nietzsches Philosophie der ewigen Wiederkunft des Gleichen (Nietzsche's Philosophy of the Eternal Recurrence of the Same) in 1935, in the capital of Hitler's Germany. By 1935 several other German presses and journals had already begun to refuse to publish Löwith's work, including Kantstudien. Indeed, the entire Appendix to Nietzsches Philosophie der ewigen Wiederkunft des Gleichen could not be published in the 1935 edition, primarily because it consisted of twelve book reviews, each one of which incisively critiqued the author under review, including Alfred Baeumler, a Nazi Party hack and thirdrate scholar whose 1931 publication Nietzsche: Der Philosoph und Politiker ("Nietzsche: The Philosopher and Politician") had become a staple of the Party's propaganda machine and made Baeumler, in effect, the "official" interpreter of Nietzsche for the Nazis. To appreciate the fully noxious aroma in Germany when Löwith's classic work was written, it should also be recalled that Nietzsche's sister, Elisabeth FörsterNietzsche, was still alive at the time that Löwith submitted his manuscript to Bahlsen from Rome. There were very few Germans who rivaled Elisabeth in her admiration for Hitler and the Party, and none who worked as diligently as did she to accommodate Nietzsche's writings to Nazi ideology.

To be sure, while much of this may help to explain the initial lack of influence of Löwith's book in Germany, none of this explains why the English-speaking community should have ignored Löwith's Nietzsche book for so long. Indeed, should not his status as a virtual persona non grata in Nazi Germany have recommended him to us instead?

There are many possible and competing explanations for this incongruity. The most obvious one is that Löwith's book does not rise to the stature of other already-translated Nietzsche studies-for example, Karl Jaspers's Nietzsche und das Christentum (1938, translated as Nietzsche and Cbristianity, 1961), his Nietzsche (1936, translated 1965), Georg Simmel's Schopenhauer und Nietzsche (1907, translated as Schopenhauer and Nietzsche, 1986), or Hans Vaihinger's Die Philosophie des Als Ob (1911, translated as The Philosophy of "As If, ${ }^{,} 1924$ ), to mention only some of the better-known translated works that deal with Nietzsche. There is no a priori way to settle such an important

from Löwith published as Martin Heidegger and European Nihilism, ed. Richard Wolin, trans. Gary Steiner [New York: Columbia University Press]). 
question. The reader must study each author's translated Nietzsche commentary, compare it with this Löwith volume, and then decide.

My own hunch is strikingly different. Just as his Jewish ancestry functioned as a defeating condition, in Germany, for serious study of Nietzsche's Philosophy of the Eternal Recurrence of the Same, his well-known differences with Heidegger and especially their differences about Nietzsche played a similar role in the United States. Heidegger's influence among English-speaking professors of philosophy who are (mistakenly) characterized as "Continental philosophers" 3 has been nothing short of extraordinary from the 1960s until today. It is no exaggeration to say that Heidegger is widely regarded among SPEPies ${ }^{4}$ as the most important philosopher of our times. For those of us who have witnessed the recent revival of an old controversy concerning Heidegger's relationship to the Nazis, the zealousness and idolatry of American Heideggerians is difficult to overestimate. Given this milieu, Löwith's Nietzsche study drew limited-and often unsympatheticattention.

What, then, recommends Nietzsche's Philosophy of the Eternal Recurrence of the Same? Until the 1930s, Nietzsche was almost universally regarded-in Germany and beyond its borders-primarily as a literary phenomenon. He had been elevated to the status of a prophet by Stefan George and his circle of poets, and was considered a critic of culture by others. His initial, most lasting, and most prominent appropriation, however, was literary: André Gide in France; Gottfried Benn, Robert Musil, and Hermann Hesse in Germany; the Russian symbolists Vyacheslav Ivanov, Andrei Belyi, and Valeri Bryusov; William Butler Yeats and George Bernard Shaw (whose Man and Superman debuted on the London stage in 1903) in England; and August Strindberg in

3. There is a double mistake made in speaking of Anglophones as "Continental philosophers." The first is that virtually all are teachers, who happen to make their living teaching philosophy courses. It is no more obvious that the approximately ten thousand persons who teach philosophy courses for a living in the United States deserve to be called "philosophers" than would be the case if we started to call thirty thousand professors of English "writers." The second mistake is that Anglophone "Continental philosophers" are not Continental either. They are persons who typically earn their keep by teaching the works of those who are Continental philosophers. If there is any confusion about this, I know of no Anglophone "Continental philosopher" who is taught on the Continent. It would be just as misleading to call an Anglophone philosopher who taught Chinese philosophy-but was not Chinese-a "Chinese philosopher."

4. I refer to members of the Society for Phenomenology and Existential Philosophy (of which I, too, am a member), numbering approximately eleven hundred-10 percent of all teachers of philosophy in these United States. 
Sweden. There were other appropriations of Nietzsche as well, of course, from Georg Brandes and Gabriele D'Annunzio to the musical tributes of Gustav Mahler, Frederick Delius, and Richard Strauss.

To the extent that Nietzsche figured at all specifically as a philosopher, however, he was lumped together with Georg Simmel, Ludwig Klages, and Henri Bergson during the early part of this century; or else he was dismissed by his contemporaries altogether-by Wilhelm Dilthey, for example. With the exception of Martin Heidegger's Nietzsche lectures delivered from 1936 to 1940-and published in 1961no one other than Jaspers and Löwith was able to argue successfully that Nietzsche was, first and foremost, a philosopher.

Jaspers stressed Nietzsche's writings as a sort of philosophical activity rather than a congealed body of theses or doctrines, an existential demonstration that all alleged certainties could be hurled into a vortex of endless reflection, a vortex from which no fixed doctrine, teaching, or thesis could survive unchallenged. In stark contrast, Heidegger argued the by now familiar thesis that Nietzsche was the last metaphysician of the West, an inverse Platonist in whose writings the last logical consequences of Platonism are exhausted, all of which are a consequence of the forgetfulness of Being (Sein) and the transformation of "truth," through Plato-from the self-disclosure of beings in their Being, to the correspondence of beliefs to states of affairs. Within Heidegger's metahistory of philosophy, Nietzsche's "will to power" became the essence (essentia) of beings whose existence (existentia) took the form of "the eternal recurrence of the same." In an earlier, Kantian vocabulary, "will to power" could be regarded as noumenal reality, as the thing in itself, and "eternal recurrence" could be regarded as mere appearances (phenomena).

Karl Löwith's Nietzsche's Philosophy of the Eternal Recurrence of the Same shares with Jaspers and Heidegger the impulse and achievement of situating Nietzsche squarely in the philosophical rather than the literary tradition. That is where the similarities end, however. Löwith's extraordinary book wears its thesis on its sleeve, on its title: Nietzsche is a philosopher and, specifically, he is the philosopher of "the eternal recurrence of the same." Moreover, Löwith situates the genre of Nietzsche's philosophy in the title and the subtitle of his first chapter, "Nietzsche's Philosophy: A System in Aphorisms." By privileging the doctrine (Lebre: teaching) of eternal recurrence as the central organizing concept of Nietzsche's "system in aphorisms," Löwith de- 
parts markedly and brilliantly from Heidegger's attempts to make the doctrines of the will to power and eternal recurrence compatible; and he departs as well from Jaspers's tendency to eschew the very possibility that a coherent philosophical position lurks beneath Nietzsche's aphorisms.

As the reader will see, Löwith surfaces with enormous clarity the paradox he believes he finds latent within Nietzsche's doctrine of eternal recurrence itself. On the one hand, argues Löwith, eternal recurrence is a cosmological theory replete with a history he traces back at least to Heraclitus. In all of its formulations, however, it suggests that, roughly, a finite number of states of the world is destined to unfold in time-which is infinite, not finite. Hence, given the finite number of possible states of the world and the infinity of time, any single state of the world must recur. More than that, it must recur eternally: the eternal recurrence of the same. At the same time, however, Nietzsche's aphorisms also exhort an imperative, namely the injunction to live in such a way that you would gladly will the eternal recurrence of your life-without change or emendation-over and over again.

The cosmological version, which Löwith sometimes characterizes as "a physical metaphysics," would on the surface seem to be incompatible with the ethical imperative to choose to live each moment in such a way that you could will its eternal recurrence. How could one will a state of affairs which-given the cosmological account-will have to occur no matter what one wills? Is there not a fatalism implicit in the doctrine of the eternal recurrence of the same which renders any imperative impotent? Even the decision to live in such a way that you would gladly will the eternal recurrence of each and every moment of your life would seem to be predestined, as would its rejection or indifference. How can one will what must happen in any case?

Löwith argues that this paradox breaks Nietzsche's central and unifying doctrine of eternal recurrence into "incommensurable shards." For Löwith this was an inevitable consequence of Nietzsche's attempt to tether a "physical metaphysics" to an "atheistic religion." This tension that Löwith diagnoses in Nietzsche is best captured in a note Nietzsche himself later discarded rather than publish: "The task is to live in such a way that you must wish to live again-you will anyway!" ("So leben dass du wünschen musst wieder zu leben ist die Aufgabedu wirst es jedenfalls!"). The task given us would appear to be undermined by the final interjection "you will anyway!" since it seems to 
deprive this task of any choice of outcomes-including accepting or rejecting the very task itself.

I encountered Löwith for the first time as an undergraduate, when I read his Meaning in History. It was not until the early 1960s, while I was thinking about possibly writing a doctoral dissertation on Heidegger and Nietzsche, that I stumbled across Löwith's Nietzsche's Philosophy of the Eternal Recurrence of the Same. I read it with interest and enthusiasm, although I rejected its major theses as well as much of its argument. It would therefore have been highly misleading to suggest that it had a great deal of influence on me.

Or so I thought.

It is not until recently, three decades later, that I have come to realize that virtually all of my writings on Nietzsche-whether books or articles-have been in unconscious and unwitting conversation with Löwith's book. My first book on Nietzsche, for example, which treated the doctrine of eternal recurrence as an "existential imperative," clearly moves within the framework established by Löwith. Why else would I have singled out the doctrine of eternal recurrence as the unifying notion that motivates all of Nietzsche's writings (apart from the textual evidence, of course)? This is especially obvious-with $20 / 20$ hindsight-in my early and sustained attempts to debunk the doctrine of eternal recurrence as a cosmological hypothesis. Granted that the cosmological construal of eternal recurrence was still much in vogue when I first began to write Nietzsche's Existential Imperative, I can no longer believe that this alone, or even primarily, explains why I spent so much time and energy trying to show that Nietzsche's published and unpublished writings render moot his commitment to the doctrine of eternal recurrence in its cosmological form. And why would I have spent so much intellectual and analytical energy showing the conceptual impossibility of a coherent version of eternal recurrence as a physical theory? Surely Löwith's shadow, deeply repressed, was cast over the pages I wrote. In innumerable ways-I now realize-I am still in dialogue with Löwith. Perhaps all that has been done is to update the vocabulary of the fundamental distinctions Löwith introduced into the Nietzsche debate.

This belated recognition and confession does not, of course, say very much about the stature I have claimed for Nietzsche's Philosophy of the Eternal Recurrence of the Same as a classic work of Nietzsche scholarship. All it shows is my unacknowledged (and unconscious) indebt- 
edness. It does seem to me, however, that those of us who have been emancipated from Heidegger's Nietzsche ${ }^{5}$ and have nonetheless continued to grapple with the doctrine of eternal recurrence, as well as with its connection to other themes in Nietzsche's philosophical arsenal-Arthur C. Danto, Maudemarie Clark, Tracy B. Strong, Richard Schacht, Alexander Nehamas, Kathleen M. Higgins, Gary Shapiro, and many others-owe Löwith a debt of gratitude, whether we are aware of it or not. In many, many ways, Löwith's Nietzsche established the framework within which much Anglophone Nietzsche scholarship has moved in the past three decades and is likely to continue to move at the onset of the new millennium.

Like the literary figure "misprision," which Harold Bloom has employed to such good affect in his The Anxiety of Influence, it is time to recognize the shoulders upon which we have been standing, even as our eyes are turned in different directions.

Bernd Magnus

Big Bear Lake, California

4 February 1996

5. I don't intend to demean Heidegger's influential Nietzsche. Far from it. It is one of the most suggestive Nietzsche studies in any language. What is wrong with it as Nietzsche commentary, however, is the same thing that is wrong with his work on Kant-for example, his Kant and the Problem of Metaphysics. Many decades after its publication, after all of its deficiencies had been discussed to death, Heidegger told a friend of mine: "It may not be good Kant, but it is awfully good Heidegger." I feel the same thing can be said of Heidegger's Nietzsche studies: They may not be good Nietzsche, but they are first-rate Heidegger. 
